16. Razbehaeva L. P. Tsennostnye osnovanyia humanytarnoho obrazovanyia : monohrafyia.[Value bases of humanitarian education : Monograph], Volhohrad : Peremena, 2001.289 s.

17. Rakhlevskaia L. K. Pedahohycheskaia antropolohyia (chelovekovedenye) v systeme neprerbvnoho obrazovanyia (ystoryia, teoryia, praktyka). [Pedagogical anthropology (human science) in the system of continuous education (history, theory, practice)]. Tom. hos. ped. un-t, Tom. hos. ped. kolledzh. Tomsk : TPHU, 1997. 159 s.

18. Slobodchykov V. I. Antropolohicheskaia perspektiva sovremennoho obrazovanyia. [Anthropological perspective of modern education] Moskva; Ekaterynburh : Izdatelskyi otdel Ekaterynburhskoi eparkhyy, 2009. 264 s.

19. Filosofiia osvity : navch. posib. / za zah. red. [The philosophy of education]. V. Andrushchenka, I. Peredborskoi. K. : Vyd-vo NPU imeni M. P. Drahomanova, 2009. 329 s.

20. Fikhte I. H. O dostoynstve cheloveka. Sochynenyia. [On the dignity of man.Works]. Raboty 1792-1801. M. : Ladomyr, 1995. $656 \mathrm{~s}$.

21. Flithner W. Systematische Pädagogik. Versuch eines Grundri.

\title{
Herasymenko A.S. The concept of moral autonomy of I. Kant in the historical and cultural discourse of pedagogical anthropology
}

The concept of I. Kant's moral autonomy in the historical and cultural discourse of pedagogical anthropology is explicated in the article. It is proved, that the development of pedagogical knowledge occurs through the acquisition of anthropological ideas and views which being transformed in the subject field of pedagogy set the principles and norms of pedagogical activity. That is why the modern "anthropological renaissance» and the extension of its problems in the new educational paradigm requires a rethinking of the cultural and historical experience of pedagogical science and, above all, the moral anthropology of Immanuel Kant.

It is observed that the historical and cultural discourse of pedagogical anthropology is now actualized by the Kant ideas of the autonomy of morality, the self-worth of moral principles and the need for moral education, which is the main pedagogical task as morality captures the degree of personal development, manifesting a deep essence of man. It is substantiated that human dignity is the highest criterion for the observance of the I. Kant moral law, the manifestation of which is the "moral law in me», by which the thinker builds the perspective of transformation of human nature in accordance with the ideal of humanity, which becomes possible through education. It is proved that morality in the discourse of Kant pedagogical thinking is the fundamental form of the educational process aimed at achieving moral purity of a person, guided by moral imperatives. It is stated that the concept of Kant's moral autonomy captures the need to attain the moral heights of man and society. In this regard, according to Kant the idea that social life is a continuous process of moral improvement of humanity becomes especially important.

Further research prospects are related to the fact that the Kant anthropological model of pedagogy is able to enrich the educational space with new search intentions and to establish pedagogical anthropology in the status of educational process methodology.

Key words: morality, autonomy of morality, moral law, moral education, dignity, pedagogical anthropology.

УДК 378.1:379.85

DOI https://doi.org/10.31392/NPU-nc.series5.2019.71.17

Гончар Л. В.

\section{ІННОВАЦЙНІ ПІДХОДИ У ФАХОВІЙ ПІДГОТОВЦІ МАЙБУТНІХ МЕНЕДЖЕРІВ}

Проаналізовано проблему формування професійної культури майбутнього менеджера. Розкрито сутність понять «інновачійний процес», «освітня інновачія», «навчальний інновачійний прочес», «професійна культура», «професійна культура менеджера» з точки зору різних наукових підходів.

Автор визначає поняття «освітні інновачії», яке розглядається як складний цілеспрямований процес впровадження, засвоєння, використання та поширення у навчальній діяльності нових ідей, замовлень, звичаїв, методів, прийомів, технологій, механізмів, систем, структури, явища тощэ з метою забезпечення його стабільності, підвищення ефективності та розвитку в ринкових умовах.

Рівні новизни: висвітлюється абсолютна новизна, локально абсолютна новизна, умовна новизна, суб'єктивна новизна. Охарактеризовано сутність освітніх нововведень у формуванні професійної культури майбутніх менеджерів. Науково обгрунтована класифікація освітніх інновацій за сферою впровадженн - науково обтрунтована; спосіб виникнення; обсяг та глибина інновачійного прочесу; основою, на якій вони з'являються, є нововведення; масштаб конверсій; інноваційний потенціал; залежно від позиції свого попередника; місця походження; рівень очікувань, прогнозування та планування; області педагогічних знань тощзо.

Виокремлюють компоненти педагогічних інновацій у формуванні професійної культури майбутніх керівників. Найбільш пріоритетні напрями навчання менеджерів із впровадженням серед них інноваиійних технологій: навчання з розробки модулів, інформаційно-комунікаційні технології, бізнес, психоекономічні, інтелектуальні тренінги, ділові ігри, тренінги, мозковий штурм, ігри для об 'єднання, де виявляються конфлікти та критичні ситуачї в командах.

Ключові слова: інновачії, майбутні менеджери, освітня інновація, професійна культура. 
Вимоги до особистісних якостей майбутніх управлінців значно зросли у зв’язку з сучасними глобалізаційними, міграційними та інтеграційними процесами у суспільстві. Відтак, сучасний менеджер повинен володіти не тільки грунтовними професійними знаннями, але й уміти ефективно застосовувати наукові методи аналізу, діагностувати проблему, пропонувати альтернативні рішення, коригувати діяльність організації; оперативно приймати управлінські рішення; вирішувати нестандартні проблеми; володіти кваліфікацією на рівні прийнятого рішення; володіти комунікативністю, комунікабельністю, вирізнятися стратегічністю мислення; наявністю певного рівня економічних, організаційно-управлінських, психологічних, технічних та інших знань, необхідних для вирішення професійних завдань.

Сучасні євроінтеграційні процеси України є невід'ємними реаліями сьогодення. За таких умов виникає необхідність у вихованні професійно компетентного, мобільного, конкурентоспроможного фахівця. Потрібні нові гуманістично-орієнтовані молоді лідери, здатні до продуктивного співробітництва, продукування неординарних ідей, готові до прийняття рішень і несення відповідальності за себе та свою діяльність.

У Національній доктрині розвитку освіти України у XXI столітті особлива увага приділяється пошуку інноваційних підходів до професійної підготовки педагогічних кадрів, спроможних забезпечити умови для розвитку й самореалізації кожної особистості, навчати й виховувати генерацію нових поколінь, здатних до життедіяльності за умов ринкових відносин. Відповідно до вимог, які висуваються до сучасного працівника освіти, важливе місце в структурі професійно-педагогічної культури має належати управлінській культурі вчителя, оскільки, з одного боку, він є керівником і організатором життя та діяльності учнів, з іншого, повинен готувати своїх вихованців до життя за нових економічних умов. Саме тому дуже важливим $є$ аналіз інноваційних підходів у формуванні професійної культури майбутніх менеджерів.

Аналіз наукової літератури з проблеми дослідження дає підстави стверджувати, що сутності феномену професійної культури майбутніх менеджерів присвячені праці багатьох науковців: В. Вакуленка, Л. Вікторової, Л. Даниленка, О. Дубасенюк, В. Жукової, Г. Зарипової, І. Коновальчука, В. Кременя, Н. Пашкус, Г. Клімової, С. Мірошника, О. Шапран, Л. Шевченко, Т. Яровенко та інших.

Мета статті полягає в теоретичному аналізі поглядів науковців щодо інноваційних підходів до формування професійної культури майбутніх менеджерів.

Термін «професійна культура» підкреслює, що культура розглядається як специфічна якість діяльності фахівця та розкриває предметний зміст культури, який визначається специфікою професії, професійної діяльності та професійного співтовариства [8]. Термін «професійна культура менеджера» розглядається науковцями як високий рівень професіоналізму людини, спосіб творчої самореалізації в професійній діяльності, процес освоєння, передачі професійних цінностей, становлення системи особистісних сенсів, які розглядаються як ступінь якості професійної діяльності та життя людини [8].

Дослідники формулюють інноваційні підходи як «набори методів і засобів, що підтримують етапи реалізації нововведення» та розрізняють такі їх рівні: абсолютна новизна; локально-абсолютна новизна; умовна новизна; суб'єктивна новизна. Абсолютна новизна охоплює принципово невідомі раніше новації, які внаслідок їх реалізації стають радикальними нововведеннями. Локально-абсолютна новизна полягає в оновленні одного з елементів системи, коли вона стає новою в якомусь одному відношенні. Умовна новизна виявляється, якщо раніше відома педагогічна ідея, концепція чи технологія знаходить втілення в нових умовах. Суб 'єктивна новизна носить суб' єктивний характер, коли об'єкт є новим для цього суб'єкта, наприклад, коли педагог стикається з чимось новим для себе, навіть якщо це добре відомо багатьом його колегам [2, с. 46].

У контексті дослідження важливо також з'ясувати сутність такої категорії як «інноваційний освітній процес». Глосарій сучасної освіти поняття «інноваційний освітній процес» трактує як системну організовану сукупність послідовно здійснюваних видів діяльності по створенню, освоєнню, використанню та поширенню нововведень, а інноваційний процес у сфері освіти - як оновлення і зміну концепцій освіти, змісту навчальних програм, методів і методик, способів навчання і виховання, процес здійснення педагогічних технологій [3, с. 141].

Вивчення наукового досвіду В. Вакуленко, Л. Вікторової, Л. Даниленко, О. Дубасенюк, В. Жукової, Г. Зарипової, І. Коновальчука, В. Кременя, Н. Пашкус, Г. Клімової, С. Мірошника, О. Шапран, Л. Шевченко, Т. Яровенко та інших дає авторам можливість запропонувати власне визначення категорії «освітня інновація». На важливості поетапності запровадження інновацій у практику професійної підготовки менеджерів наголошують й інші дослідники освітніх інновацій, зокрема К. Гораш, Р. Горбатюк, І. Коновальчук, Л. Литвин, Л. Марченко та інші.

На думку авторів, «освітня інновація»- це комплексний, изілеспрямований процес втілення, засвоєння, використання та поширення в освітній діяльності нових ідей, порядків, звичаїв, методів, прийомів, технологій, механізмів, систем, структур, явищ тощуо з метою забезпечення ї̈ стабільності, підвищення рівня ефективності та розвитку в ринкових умовах.

Для отримання всебічної характеристики сутності освітніх інновацій у формуванні професійної культури майбутніх менеджерів важливе значення має науково обгрунтована їх класифікація, яка дає можливість зрозуміти глибину їх ролі, завдання та функції в організації освітньої діяльності.

Прийнятними для дослідження є підходи, представлені у наукових працях К. Ангеловські, Л. Даниленко, I. Дичківської, А. Хуторського. Автори не розділяють думки, що такі класифікаційні ознаки як організація 
і система управління (К. Ангеловські), інновації в управлінні освітою (оновлення структури, організації і керівництва освітніми закладами) (І. Дичківська); форми і методи управління закладами освіти, інновації у змісті, структурі, формах і методах управління закладами освіти (Л. Даниленко), управлінські нововведення (нові рішення у структурі освітніх систем і управлінських процедурах, що забезпечують їх функціонування) (А. Хуторський) належать до педагогічних. На думку авторів, їх доцільно віднести до освітніх інновацій. Враховуючи, що педагогічні інновації є складником освітніх.

Так, К. Ангеловські педагогічні інновації класифікує за сферою впровадження - інновації у змісті освіти, формах, методах, засобах навчання, організації і системі управління; способом виникнення - новації систематичні, планові, заздалегідь продумані, стихійні, спонтанні, випадкові; обсягом і глибиною інноваційного процесу - масові, масштабні, глобальні, стратегічні, систематичні, радикальні, фундаментальні, глибокі, часткові, малі, неглибокі; за основою, на якій виявляються, виникають нововведення - зовнішні та внутрішні [1, с. 37].

I. Дичківська, педагогічні інновації поділяє на такі групи:

1. Залежно від сфери застосування:

1) інновації у змісті освіти (оновлення змісту навчальних програм, підручників, посібників тощо);

2) інновації в технології навчання і виховання (оновлення методів викладання та взаємодії у виховному процесі);

3) інновації в організації педагогічного процесу (оновлення форм і засобів здійснення навчально-виховного процесу);

4) інновації в управлінні освітою (оновлення структури, організації і керівництва освітніми закладами);

5) інновації в освітній екології (архітектурне планування освітніх закладів, використання будівельних матеріалів, інтер'єрів приміщень тощо).

2. Залежно від масштабу перетворень:

1) часткові (локальні, одиничні) нововведення, не пов’язані між собою;

2) модульні інновації (комплекс пов'язаних між собою часткових нововведень, що належать до однієї групи предметів або однієї вікової групи дітей тощо);

3) системні інновації (охоплюють весь навчально-виховний заклад) та передбачають перебудову всього закладу під певну ідею, концепцію або створення нового освітнього закладу на базі попереднього.

3. Залежно від інноваційного потенціалу:

1) модифікаційні інновації (пов'язані з удосконаленням, раціоналізацією, видозміною, модернізацією того, що має аналог або прототип);

2) комбінаторні інновації (передбачають нове конструктивне поєднання елементів раніше відомих методик, які в такому варіанті ще не використовувалися);

3) радикальні або фундаментальні, глобальні, базові інновації (вони, як правило, є відкриттями, що найчастіше виникають у результаті творчої інтеграції і сприяють створенню принципово нових навчальних засобів).

4. Залежно від позиції щодо свого попередника:

1) замінні нововведення (їх запроваджують замість конкретного застарілого засобу);

2) скасовуючі інновації (суть їх полягає у припиненні діяльності певних органів, об'єднань, у скасуванні форми роботи, програми без заміни їх іншими за умови їхньої неперспективності з огляду на потреби розвитку навчального закладу);

3) відкриваючі інновації (передбачають освоєння нової програми, нового виду освітніх послуг, нової технології тощо);

4) ретровведення (освоєння в навчально-виховному закладі того, що існувало в педагогічній практиці раніше).

5. Залежно від місця виникнення:

1) інновації в науці (оновлення педагогічної теорії);

2) інновації в практиці (оновлення педагогічної практики).

6. Залежно від часу появи:

а) історичні інновації (відродження історико-педагогічної спадщини в нових умовах);

б) сучасні інновації (інновації сьогодення).

7. Залежно від рівня очікування, прогнозування і планування:

1) очікувані (планові) інновації;

2) неочікувані (незаплановані) інновації.

8. Залежно від галузі педагогічного знання:

а) виховні інновації (у галузі виховання);

б) дидактичні інновації (у галузі навчання);

в) історико-педагогічні інновації (у галузі історії педагогіки) тощо [4, с. 33-36].

На думку Л. Даниленко, класифікацію педагогічних інновацій у формуванні професійної культури майбутніх менеджерів слід розглядати на основі педагогічного процесу та його складників: інновації у змісті навчання і виховання; інновації у формах, методах, технологіях навчання; інновації у змісті, структурі, формах і методах управління закладами освіти [5, с. 72]. 
Впровадження в освітній процес закладів вищої освіти інноваційних підходів є одним із напрямів підготовки менеджерів. На думку Є. Фатєєвої, до найбільш пріоритетних напрямів підготовки менеджерів із впровадженням інноваційних технологій можна віднести модульно-розвиваюче навчання та інформаційнокомунікативні технології [8].

Т. Вахрушева серед новітніх засобів і методів навчання майбутніх менеджерів виділяє ділові, психолого-економічні, інтелектуальні тренінги, ділові ігри, коучинг-тренінги для набуття нових якостей та вмінь, мозковий штурм, ігри на згуртування колективу, моделювання нестандартних, конфліктних і критичних ситуацій тощо [2].

Л. Марченко, акцентуючи увагу на процесі впровадження нововведень у практику професійної підготовки менеджерів, пропонує модель інноваційного процесу, яка охоплює шість етапів: 1) виявлення потреби у нововведенні (виявлення й аналіз проблеми, усвідомлення потреби у нововведенні, переконання суб'єктів організації в необхідності нововведення); 2) збір інформації про можливі нововведення, які забезпечать розв’язання проблеми (пошук інформації щодо способів розв'язання подібних проблем, виявлення варіантів інноваційних рішень); 3) оцінювання інноваційних проектів за критеріями здійснення й освітньої доцільності (розроблення інноваційних проектів, оцінювання прогнозних результатів впровадження кожного проекту, вибір інноваційного проекту); 4) прийняття рішення про впровадження інновації (рішення про доцільність впровадження відібраного інноваційного проекту, ухвалення рішення вищим керівництвом); 5) впровадження нововведення (пробне впровадження, повне впровадження, використання); 6) інституціоналізація нововведення (рутинізація, модифікація, дифузія) [8].

Впровадження інноваційних ідей частіше за все виявляє значні труднощі на практиці, серед яких значна вага лежить на психологічних чинниках: стереотипності, консервативності тощо. Особливу важливість у їх подоланні може грати гнучкість мислення учасників інноваційного процесу. У зв'язку 3 цим постає актуальним завдання на етапах підготовки бакалаврів та магістрів закладати фундамент цілісного (правильного) мислення менеджерів, яке буде включати таку компетенцію менеджерів до власного психологічного менеджменту за допомогою рефлексії як основи для виділення в навколишньому середовищі нових об'єктів, нових зв'язків між ними, побудови нових категорійних моделей, пошуку нових способів представлення їх поняттєвої сутності та онтологічної інтерпретації проектної діяльності [6, с. 110]. Йдется про окремий вид мислення - «інноваційне мислення», яке уподібнюють гнучкому, креативному, творчому. Воно визначається як здатність людини змінювати настанови в умовах постійно змінної реальності.

Висновки. Для того, щоб забезпечити стабільний процес формування професійної культури майбутніх менеджерів і здобути пролонгований позитивний ефект від запровадженої освітньої інновації, доцільно постійно підтримувати життєвий цикл нововведення, своєчасно вносячи зміни, вдосконалюючи та модернізуючи його. Слід також запроваджувати на рівні форм та методів викладацької діяльності ефективні сучасні ідеї щодо формування інноваційного (правильного) мислення у менеджера, прищеплювати студентам навички опанування дійовими технологіями саморозвитку та самонавчання фахівця протягом усього професійного періоду життя.

\section{Використана література:}

1. Ангеловски К. Учителя и инновации. М. : Просвещение, 1991. 159 с.

2. Вахрушева Т. Теоретичні аспекти активних методів. Педагогіка, психологія та медико-біологічні проблеми фізичного виховання і спорту. 2008. № 3. С. 46-49.

3. Астахова В. И. Глоссарий современного образования. Харьков : Изд-во НУА. 2014. 532 с.

4. Дичківська І. Інноваційні педагогічні технології : навч. посібник. К. : Академвидав. 2004. 352 с.

5. Дубасенюк О. А. Інновації в сучасній освіті. Інновації в освіті: інтеграція науки і практики : збірник науково-методичних прачь. Житомир : Вид-во ЖДУ ім. І. Франка. 2014. С. 12-28.

6. Литвин Л. Менеджмент освітніх інновацій: сутність та особливості впровадження. Соціально-економічні проблеми і держава. 2013. Вип. 1(8). С. 108-115.

7. Марченко Л. Управління інноваційною діяльністю педагогів в умовах профільних загальноосвітніх навчальних закладів. Збірник наукових пращь Бердянського державного педагогічного університету: педагогічні науки. Бердянськ : БДПУ. 2009. № 2. С. 248-250.

8. Романовський О. Шляхи впровадження інновацій, підприємництва та підприємницької освіти в системі національної освіти України : Монографія. Вінниця : Нова книга. 2010. 416 с.

\section{References:}

1. Angelovski K. (1991). Uchitelya i innovatsii [Teachers and Innovations]. M. : Prosveshcheniye. 159 pp.

2. Vakhrusheva T. (20018). Teoretychni aspekty aktyvnykh metodiv [Theoretical aspects of active methods]. Pedahohika, psykholohiia ta medyko-biolohichni problemy fizychnoho vykhovannia i sportu, T. 3. P. 46-49.

3. Astakhova V. I. (2014). Glossariy sovremennogo obrazovaniya [Glossary of

4. modern education]. Kharkov : Izd-vo NUA, $532 \mathrm{p}$.

5. Dychkivska I. (2004). Innovatsiini pedahohichni tekhnolohii : navch

6. Posibnyk [Innovative pedagogical technologies: tutorial]. K. : Akademvydav, $352 \mathrm{p}$.

7. Dubaseniuk O. A. (2014). Innovatsii v suchasnii osviti [Innovation in

8. modern education]. Innovatsii v osviti: intehratsiia nauky i praktyky : zbirnyk naukovo-metodychnykh prats. Zhytomyr : Vyd-vo ZhDU im. I. Franka, P. 12-28. 
9. Lytvyn L. (2013). Menedzhment osvitnikh innovatsii: sutnist ta osoblyvosti

10. vprovadzhennia [Management of educational innovation: the essence and features of implementation]. Sotsialno-ekonomichni problemy i derzhava, Vyp. 1(8). P. 108-115.

11. Marchenko L. (2009). Upravlinnia innovatsiinoiu diialnistiu pedahohiv v

12. umovakh profilnykh zahalnoosvitnikh navchalnykh zakladiv []. Zbirnyk naukovykh prats Berdianskoho derzhavnoho pedahohichnoho universytetu : pedahohichni nauky. Berdiansk : BDPU, Vyp. 2, P. 248-250.

13. Romanovskyi O. (2010). Shliakhy vprovadzhennia innovatsii,

14. pidpryiemnytstva ta pidpryiemnytskoi osvity v systemi natsionalnoi osvity Ukrainy: Monohrafiia [Ways of introducing innovation, entrepreneurship and entrepreneurship education in the national education system of Ukraine : Monograph]. Vinnytsia : Nova knyha, $416 \mathrm{p}$.

\section{Gonchar L. V. Innovative approaches in the professional training of future managers}

The problem of forming the professional culture of the future manager is analyzed in the article. The essence of the concepts of «innovation process», "educational innovation», "educational innovation process», "professional culture», "professional culture of the manager» from the point of view of different scientific approaches is revealed.

The author defines the concept of «educational innovation», which is considered as a complex, purposeful process of implementation, assimilation, use and dissemination in the educational activity of new ideas, orders, customs, methods, techniques, technologies, mechanisms, systems, structures, phenomena, etc., for the purpose ensuring its stability, improving efficiency and development in market conditions.

Levels of novelty: absolute novelty, locally absolute novelty, conditional novelty, subjective novelty are covered. The essence of educational innovations in forming the professional culture of future managers is characterized. Scientifically substantiated classification of educational innovation by: sphere of introduction is scientifically substantiated; the way of occurrence; the volume and depth of the innovation process; the basis on which they appear are innovations; the scale of conversions; innovative potential; depending on the position of its predecessor; places of origin; the level of expectations, forecasting and planning; areas of pedagogical knowledge, etc.

The components of pedagogical innovations in the formation of professional culture of future managers are distinguished. The most priority directions of training of managers with introduction of innovative technologies among them: module-development training, information and communication technologies, business, psycho-economic, intellectual trainings, business games, coaching trainings, brainstorming, games for teaming of non-standard teams conflict and critical situations are revealed.

Key words: educational innovation, future managers, professional culture, innovation.

УДК 376.1

DOI https://doi.org/10.31392/NPU-nc.series5.2019.71.18

Гончаренко О. В., Поляничко А. О.

\section{ГЕНДЕРНЕ ВИХОВАННЯ ХЛОПЦІВ ТА ШЛЯХИ ЙОГО ОПТИМІЗАЦІЇ}

Дослідження присвячене проблемі гендерного розвитку хлопиів та необхідності його оптимізації. Авторками аналізується зміст гендерної соціалізаџії в контексті традиційного (патріархального) та сучасного (альтернативного) виховання. У контексті вивчення традииійного підходу до виховання визначено, шо в його основу покладені жорстка гендерна диференціація чоловічого і жіночого та їх суворе ієрархічне розташування. Доведено, щзо такий підхід спирається на підкреслення відмінностей між чоловіками і жінками; орієнтачію на «особливе призначення» статей; закріплення у хлопчиків гендерно-стереотипних інтересів та уподобань; ігнорування індивідуальності та обмеження свободи вибору; виховання гендерно-схематизованих індивідів. Підгрунтям для особистісного розвитку хлопців слугує образ «справжнього чоловіка», який визначається нормами статусу, твердості (фізичної, розумової, емоційної) та антижіночності. Констатовано, щчо існуючі норми, правила поведінки, установки щзодо культурних уявлень про ролі, становище і призначення чоловіка в суспільстві, які покладені в основу традиційного виховання хлопчиків, в подальшому призводять до трудношів у дорослому житті.

У статті обтрунтовуються переваги особистісно-орієнтованої моделі виховання на основі гендерного підходу, який передбачає розвиток хлопиів поза жорсткими гендерними приписами та стереотипами. Авторки переконують, щзо сучасна соціалізація передбачає відсутність гендерної диференціаџіï та поляризаиії $і$ розглядається як процес засвоєння хлопчиками нових гендерних ролей, які з 'явилися у зв 'язку з інтенсивними соціокультурними змінами. Визначено, щзо в такій моделі виховання зростає роль сім'ї $і$ закладів освіти, які повинні стати активними суб 'єктами позитивних змін у процесі гендерного розвитку чоловічої молоді.

Ключові слова: гендерний підхід, традиційне і гендерне виховання, гендерні норми, особистісно-орієнтоване виховання.

Сучасний світ і життя в ньому настільки складні, багатогранні та мінливі, що треба бути готовим до всього. Процес особистісного розвитку сьогодні відбувається в ситуації набагато більшої, ніж раніше, соціальної варіативності і невизначеності видів діяльності, соціальних ролей та іншого. При цьому подібна різноманітність і динамічність суспільного життя все частіше вступають у протиріччя 3 тими традиційними (патріархальними за змістом) вимогами і приписами, які продовжують адресуватися жінкам і чоловікам. Отже, існуючі гендерні норми вже мало відповідають реальній дійсності. 